\title{
Physicochemical Characterization and Valorization of Clay from Lobo and Ngoya in Cameroon Central Region
}

\author{
Nchare Mominou $^{1 *}$, Mache Jacque Richard ${ }^{2}$, Sabo Ina Aicha1 \\ ${ }^{1}$ Department of Mining Engineering, School of Geology \& Mining Engineering, University of Ngaoundere, Ngaoundere, Cameroon \\ ${ }^{2}$ Mission de Promotion des Matériaux Locaux, Yaoundé, Cameroon \\ Email: *nmominou@yahoo.com
}

How to cite this paper: Mominou, N., Richard, M.J. and Aicha, S.I. (2019) Physicochemical Characterization and Valorization of Clay from Lobo and Ngoya in Cameroon Central Region. Open Journal of Inorganic Chemistry, 9, 23-33.

https://doi.org/10.4236/ojic.2019.93003

Received: April 1, 2019

Accepted: June 17, 2019

Published: June 20, 2019

Copyright $\odot 2019$ by author(s) and Scientific Research Publishing Inc. This work is licensed under the Creative Commons Attribution International License (CC BY 4.0).

http://creativecommons.org/licenses/by/4.0/

\begin{abstract}
Two samples clayed materials, LO and NG from central region in Cameroon were characterized for their valorization in the manufacture of refractory bricks and ceramics. In order to assess the technological properties of these clays, cooking tests were carried out on the test specimens at different temperatures. From particle size analysis, clayed materials studied have a spreading particle size and their plasticity index is between 18 and 47 . The mineralogical study reveals the presence of Quartz, illite, kaolin, hematite and feldspars. High level of silica content explains the sandy nature of these clays. Linear shrinkage and density increase with temperature while compressive strength decreases with temperature. Analyses performed on the ceramic specimens after firing show that clay materials studied are suitable for the manufacture of refractory bricks.
\end{abstract}

\section{Keywords \\ Clay Material, Valorization, Refractory Bricks, Ceramics}

\section{Introduction}

Clays have been used by man since the beginning of time. The characteristics and chemical composition of clay deposit usually determine its industrial application [1] [2] [3]. The natural abundance and immediate availability of clays explain their great uses over time. The particularity of this material is its capacity to have a plastic state with appropriate levels of water [4]. This material also has the power to be shaped, to shrink, to harden after drying and to consolidate after firing, which allows the formation of a vitreous phase [5]. The last discovery 
(consolidation by fire) was in the same way as agriculture at the base of the first human civilization. Today, they are used as a minor constituent (paints, plastics, cosmetics, pharmaceuticals, etc.), and as a majority raw material (production of widely used ceramic materials such as building materials and decorative objects). While the consumption of these products tends to become widespread, their production remains very unsustainable in some developing countries [6]. In Cameroon, for example, most industrial clay ceramics are imported. This situation can be explained by the virtual absence of a real industrial fabric and a poor estimate of the potential of local resources. In addition to this, the low level of popularization of quality ceramic products in our context may also stem from the poor mastery of production technologies that must first be based on the mineralogical and physicochemical characterization of the natural material. The clay materials used for the production of ceramics are often complex natural mixtures of minerals whose granulometry and physicochemical properties are highly variable [4]. The user choice criteria are less related to the overall chemical and mineralogical composition of clay materials than to their behavior during the different stages of ceramic product manufacturing. This is extremely important because, due to lack of knowledge, it is often dried and cooked, giving poor quality ceramic products and generating many wastes observed at the exit of the oven [7]. Whatever the type of ceramic to be obtained, the mineralogical composition of the clay material is important because it is dependent on the specific properties of the final product. It is therefore important to master these intrinsic parameters of the natural material before adopting the best techniques of elaboration. The mastery of the intrinsic parameters of the crystalline material passes through essential analyzes among which are X-ray diffraction analysis, which makes it possible to identify the crystalline phases that follow the evolution of the process in order to detect different physico-chemical phenomena which are occurring. Some works have already been carried out on the Cameroonian clay materials based on kaolinite, illite, smectite or talc [8]. This focused on the study of the physico-chemical characteristics, the catalytic properties and the thermal behavior of some sources of clay matter. The results of this work are intended to feed a sufficiently reliable database to support the start-up of industrial projects for Cameroon local clay materials. The present work focuses on the mineralogical and physical characterization of the clay material from Lobo and Ngoya in Cameroon central region.

The main objective of this work is to study the technological ability of this material for the manufacture of ceramic products for wide dissemination and sustainable local development. This study is a scientific contribution in the knowledge and characterization of industrial minerals which contributes to the promotion of local materials in Cameroon.

\section{Materials and Methods}

\subsection{Materials}

Clay samples were collected from a well located at latitude $9.285126^{\circ}$ North and 
longitude $13.455767^{\circ}$ East. Sample from Lobo was denoted LO and sample from Ngoya was denoted NG. About $2.0 \mathrm{~kg}$ of each sample was collected and placed in small polyethylene bags. $1.0 \mathrm{~kg}$ of each sample was dried, pulverized and sieved before analysis. Documentary studies [9] suggested the clay nature of the grayish material.

\subsection{Methods}

Sieve series, a densimeter, a pycnometer, X-ray diffraction and infrared spectrometry were used to study the particle size as well as the physical and chemical properties of the material.

\section{Results and Discussion}

\subsection{Particle Size Analysis}

Table 1 summarizes the particle size distribution of different materials studied.

Sample clay material LO consists of $1.5 \%$ gravel, $55.92 \%$ sand, $6.08 \%$ silt and $36.49 \%$ clay while sample clay material NG consists of $0.6 \%$ gravel, $57.63 \%$ sand, $17.56 \%$ silt and $24.14 \%$ clay. The high percentage of sand in these samples allows us to deduce that it is clayey sand having homogeneous and spread particle size. [10].

\subsection{Physical Properties}

The results of the ATTERBERG limit test are shown in Table 2.

These clay materials have a plasticity index in the range of 18 to 47 . The sample LO has a plasticity index of $26.22 \%$ while the NG sample has a plasticity index of $17.52 \%$. These values from Table 2, make it possible to conclude that sample clay materials LO is plastic (Ip $=26.22 \%)$ while sample NG is not (Ip = $17.52 \%)$. The low plasticity of the NG sample is explained by the high proportion of sand $(57.63 \%)$ [11].

\subsection{Mineralogical Analyses}

Figure 1 and Figure 2 show the diffractograms of the clay materials. LO clay

Table 1. Particle size distribution.

\begin{tabular}{ccccc}
\hline Samples & Gravel (\%) & Sand (\%) & Silt (\%) & Clay (\%) \\
\hline LO & 15 & 55.92 & 6.08 & 36.49 \\
NG & 0.6 & 57.63 & 17.56 & 24.14 \\
\hline
\end{tabular}

Gravel: $(\phi>2 \mathrm{~mm})$, Sand: $(0.02 \mathrm{~mm}<\phi>2 \mathrm{~mm})$, Silt: $(0.002 \mathrm{~mm}<\phi>0.02 \mathrm{~mm})$ Clay: $(\phi<0.002 \mathrm{~mm})$

Table 2. Results of ATTERBERG limits for LO and NG clay materials.

\begin{tabular}{cccc}
\hline Samples & Limit of liquidity & Limit of plasticity & Plasticity index \\
\hline LO & 44.87 & 18.65 & 26.22 \\
NG & 44.87 & 27.35 & 17.52 \\
\hline
\end{tabular}




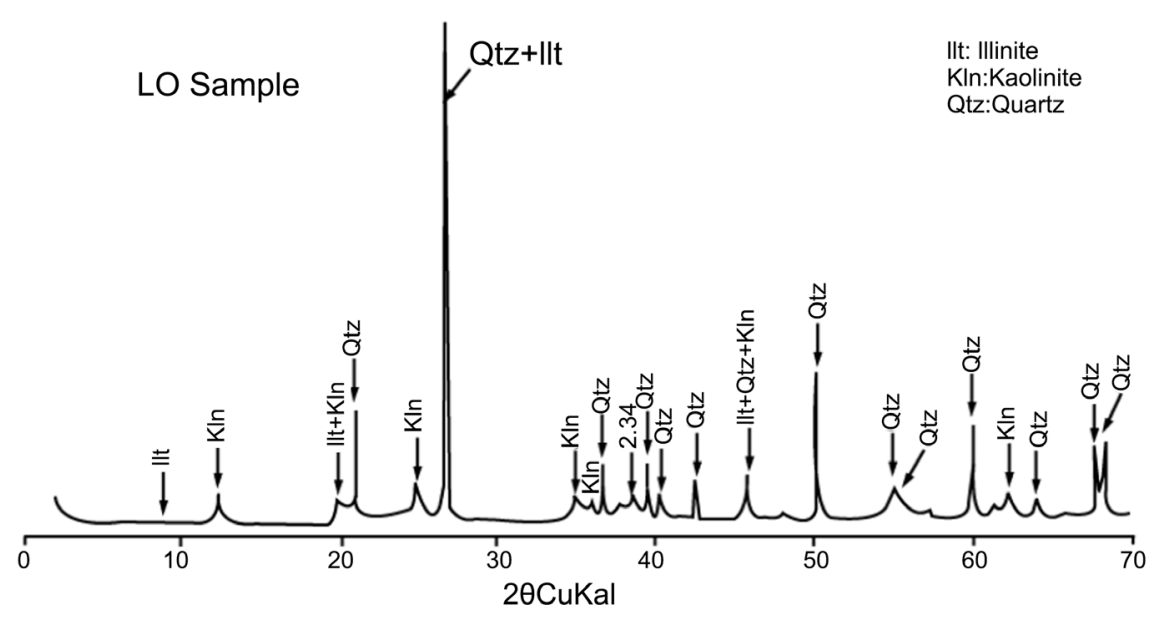

Figure 1. Diffractogram of LO clay sample.

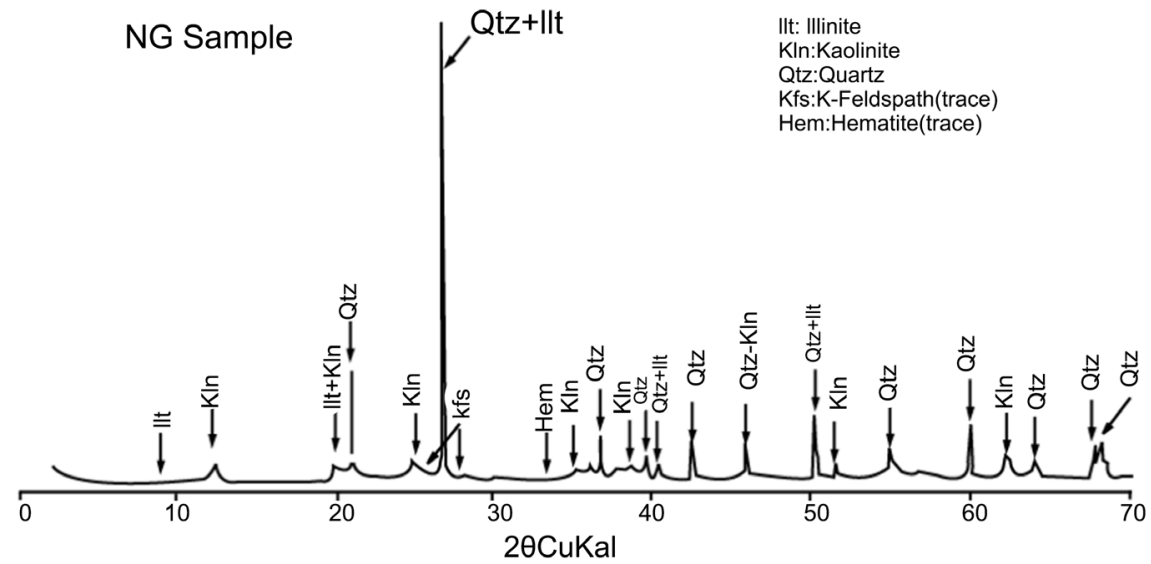

Figure 2. Diffractogram of the NG clay sample.

material consists of quartz (in the form of sand) associated with clay minerals (illite, kaolinite) while in NG clay material, in addition to quartz (in the form of sand) and kaolinite, other minerals such as k-feldspars and hematite are also present [12].

\subsection{Infrared Spectrometry}

Figure 3 and Figure 4 show the complete infrared spectra of the clay materials LO and NG respectively.

These spectra reveal two zones of absorbance; the first zone is between 4000 and $3500 \mathrm{~cm}^{-1}$ and the second zone of absorbance is between 2000 and $500 \mathrm{~cm}^{-1}$. These bands are characteristic of the elongation vibrations of the external hydroxyl $(\mathrm{OH})$ bonds of kaolinite network (Al-OH-Al) [13]. The band at 3620 $\mathrm{cm}^{-1}$ could also reflect the presence of illite [14]. The second absorbance zone is between 2000 and $500 \mathrm{~cm}^{-1}$, with absorption bands at 1030, 1000, 912, 795, 748, 685 and $533 \mathrm{~cm}^{-1}$ for LO clay sample and at 1630, 1020, 1000, 912, 791, 745, 675 and $535 \mathrm{~cm}^{-1}$ for NG clay sample. The band at $1630 \mathrm{~cm}^{-1}$ observed on NG spectrum represents the vibration of the hydroxyl $(\mathrm{OH})$ groups of the water molecules 


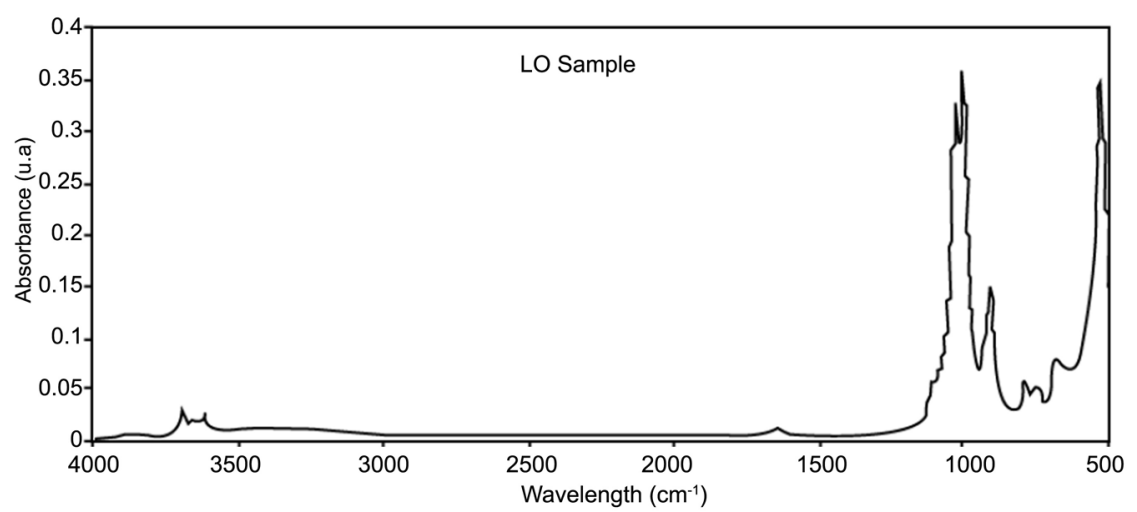

Figure 3. Full infrared spectrum of LO clay sample.

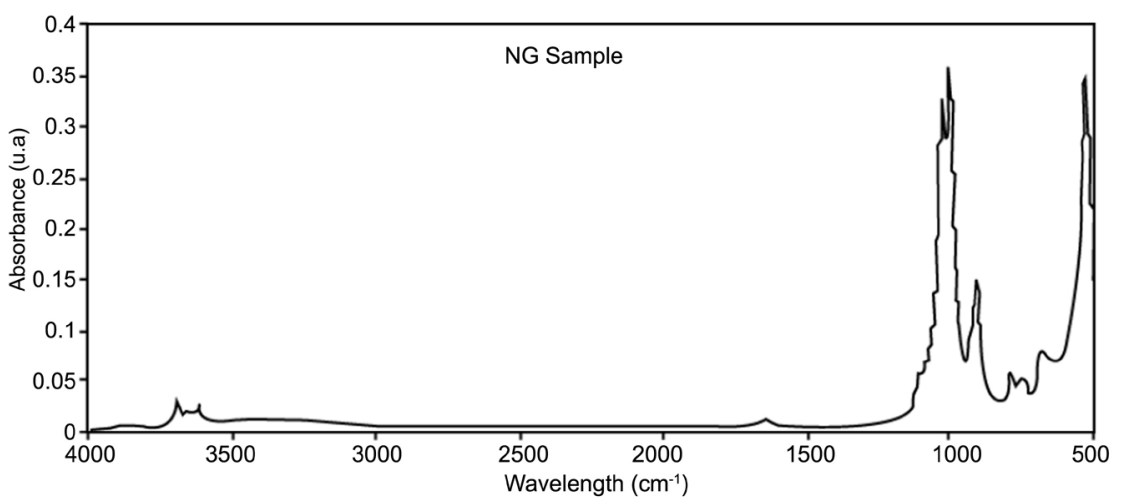

Figure 4. Full infrared spectrum of NG clay sample.

[13] and the bands at 1030 and $533 \mathrm{~cm}^{-1}$ for LO are characteristic of the Si-O bond vibrations. The bands between 795 and $675 \mathrm{~cm}^{-1}$ represent the bands relating to the quartz doublet. The $912 \mathrm{~cm}^{-1}$ bands for each sample are characteristic of Al-O bond vibration.

\subsection{Thermogravimetric Analysis}

The results of the thermogravimetric analysis are shown in Figure 5 and Figure 6.

These thermograms show five zones of anomalies: The first zone is between $100^{\circ} \mathrm{C}$ and $150^{\circ} \mathrm{C}$ and has endothermic peaks centered at $97^{\circ} \mathrm{C}$ for $\mathrm{LO}$ and at $98^{\circ} \mathrm{C}$ for NG. These peaks correspond to the mass loss of water contained in the studied materials; the second anomaly zone is between $150^{\circ} \mathrm{C}$ and $450^{\circ} \mathrm{C}$ with endothermic peaks centered at $199^{\circ} \mathrm{C}$ and $290^{\circ} \mathrm{C}$ for LO clay material, then at $220^{\circ} \mathrm{C}$ and $360^{\circ} \mathrm{C}$ for NG clay material; these peaks correspond to the dehydroxylation of phyllosilicates; the third anomaly zone is between $450^{\circ} \mathrm{C}$ and $600^{\circ} \mathrm{C}$ with endothermic peaks centered at $540^{\circ} \mathrm{C}$ for LO clay and at $520^{\circ} \mathrm{C}$ for NG clay material. These peaks are due to the dehydroxylation of kaolinite; the fourth anomaly zone is between $650^{\circ} \mathrm{C}$ and $800^{\circ} \mathrm{C}$ with endothermic peaks centered at $790^{\circ} \mathrm{C}$ for LO clay and $760^{\circ} \mathrm{C}$ for NG clay; these peaks come from the dehydroxylation of $2 / 1$ clay minerals such as illite. Losses of mass below $180^{\circ} \mathrm{C}$ are related 


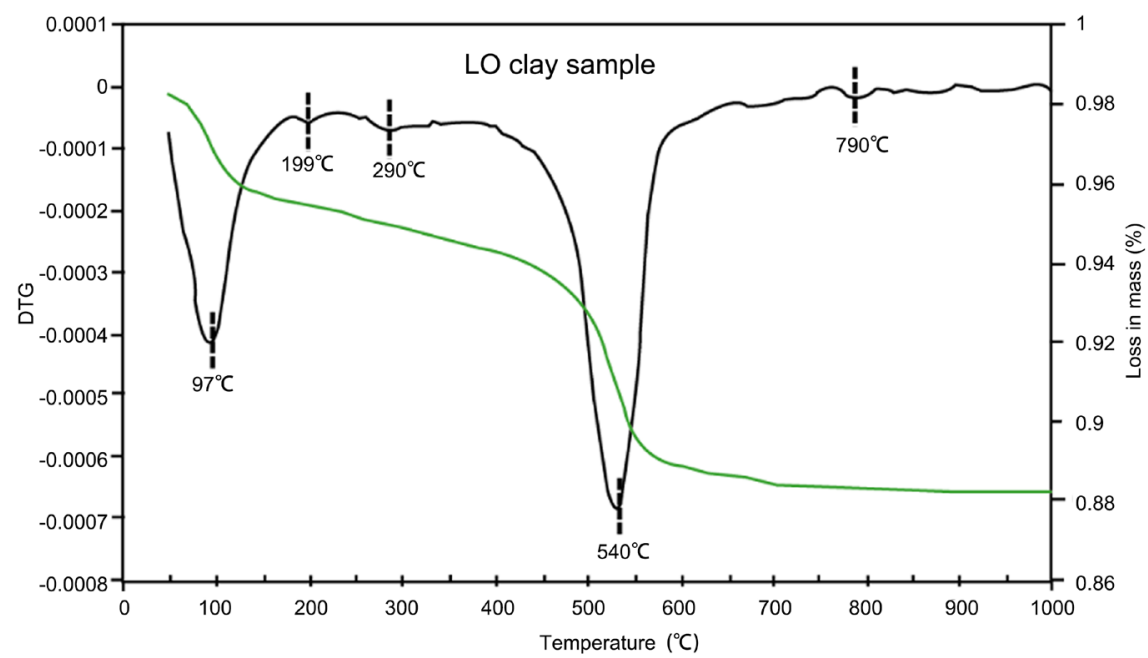

Figure 5. Differential thermogravimetric analysis of LO Clay sample.

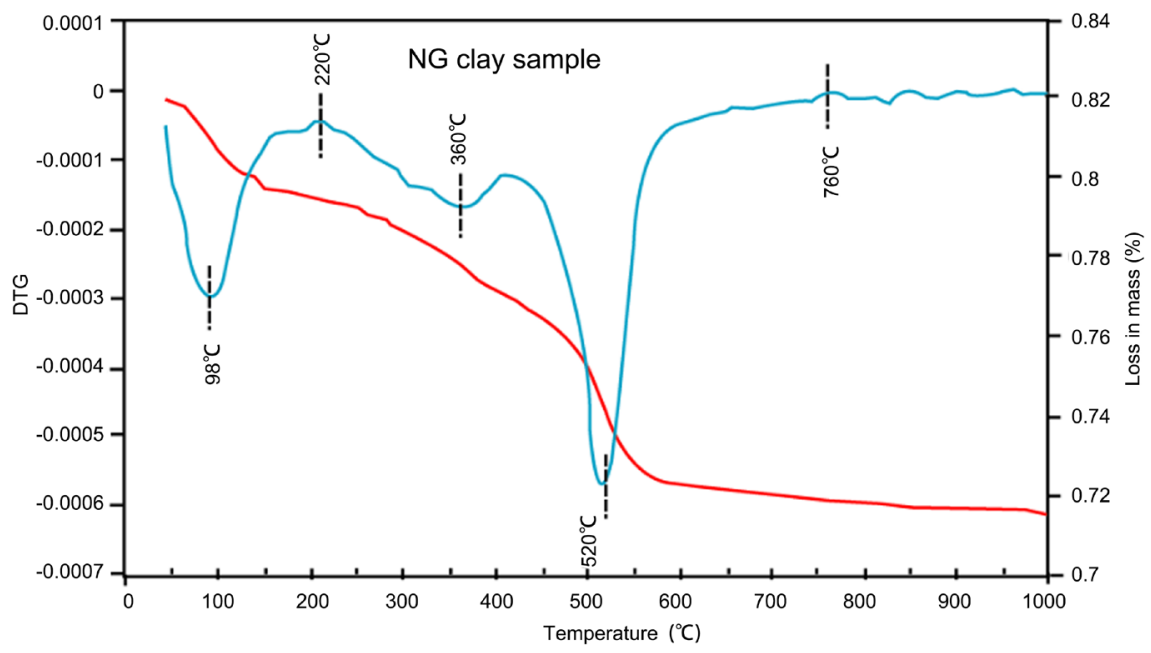

Figure 6. Differential thermogravimetric analysis of NG Clay sample.

to the disappearance of adsorbed or capillary water. Between $150^{\circ} \mathrm{C}$ and $450^{\circ} \mathrm{C}$, losses of mass are due to dehydroxylation of phyllosilicates. Mass losses observed between $450^{\circ} \mathrm{C}$ and $650^{\circ} \mathrm{C}$ are due to dehydroxylation of kaolinite to give metakaolinite which has a very poorly organized structure [14]. Mass losses recorded between $650^{\circ} \mathrm{C}$ and $800^{\circ} \mathrm{C}$ could result from the dehydroxylation of type $2 / 1$ minerals such as illite.

\subsection{Chemical Composition}

Organic matter content of LO clay material is $6.03 \%$ with a $\mathrm{pH}$ of 7.73 while NG sample has an organic matter content of $2.40 \%$ with a $\mathrm{pH}$ of 5.56 . The chemical composition of the clay materials studied is summarized in Table 3.

It can be seen from Table 3 that LO clay consists mainly of silica (64.09\%), followed by aluminum oxide (20.24\%) and titanium oxide (1.87\%). iron oxide (1.82\%), potassium oxide $(1.19 \%)$. Other oxides are present in trace such as 
Table 3. Chemical composition of clay materials.

\begin{tabular}{cccccccccccc}
\hline Samples & $\mathrm{SiO}_{2}$ & $\mathrm{Al}_{2} \mathrm{O}_{3}$ & $\mathrm{Fe}_{2} \mathrm{O}_{3}$ & $\mathrm{~K}_{2} \mathrm{O}$ & $\mathrm{MgO}$ & $\mathrm{TiO}_{2}$ & $\mathrm{P}_{2} \mathrm{O}_{5}$ & $\mathrm{CaO}$ & $\mathrm{MnO}$ & $\mathrm{Na}_{2} \mathrm{O}$ & L.O.I \\
\hline $\mathrm{LO}$ & 64.09 & 20.24 & 1.82 & 1.19 & 0.28 & 1.87 & 0.09 & 0.06 & 0.02 & 0 & 9.39 \\
$\mathrm{NG}$ & 59.12 & 22.06 & 2.34 & 1.07 & 0.19 & 1.81 & 0.17 & 0.11 & 0.03 & 0 & 12.02 \\
\hline
\end{tabular}

magnesium oxide $(0.28 \%)$, manganese oxide $(0.02 \%)$, calcium oxide $(0.06 \%)$, phosphorus oxide (0.09\%). NG clay is also mainly composed of silica (59.12\%), aluminum oxide $(22.06 \%)$, iron oxide $(2.34 \%)$, titanium oxide $(1.81 \%)$, potassium oxide $(1.19 \%)$. Other oxides are also present in trace such as magnesium oxide $(0.19 \%)$, potassium oxide $(0.17 \%)$, manganese oxide $(0.03 \%)$, calcium oxide $(0.11 \%)$. The $\mathrm{SiO}_{2}: \mathrm{Al}_{2} \mathrm{O}_{3}$ ratio is greater than $2 \% ; 3.16 \%$ for $\mathrm{LO}$ clay and $2.67 \%$ for NG clay, reflecting the abundance of sand in the studied clay materials [15] [16].

\subsection{Quality Control Test}

The quality control tests carried out are designed to evaluate certain ceramic properties such as linear shrinkage during cooking, bulk density, compressive strength, and water absorption rate. Figure 7 shows the variation in linear shrinkage of clay materials as a function of temperature.

Linear shrinkage is a parameter that reflects the reactivity of material during firing [17]. From Figure 7, it follows that the linear shrinkage increases with temperature. The shrinkage values for our materials are relatively low, therefore favorable for the manufacture of refractory bricks of good quality.

The resulting curves of apparent density are shown in Figure 8.

Figure 8 shows that apparent density increases with temperature. For LO clay, density varies very little from $2.13 \mathrm{~g} / \mathrm{cm}^{3}$ at $1000^{\circ} \mathrm{C}$ to $2.23 \mathrm{~g} / \mathrm{cm}^{3}$ at $1100^{\circ} \mathrm{C}$, then from $2.27 \mathrm{~g} / \mathrm{cm}^{3}$ to $1200^{\circ} \mathrm{C}$. For NG clay, the bulk density varies from $1.97 \mathrm{~g} / \mathrm{cm}^{3}$ at $1000^{\circ} \mathrm{C}$ to $2.09 \mathrm{~g} / \mathrm{cm}^{3}$ at $1100^{\circ} \mathrm{C}$ and at $1200^{\circ} \mathrm{C}$ the apparent density is 2.36 $\mathrm{g} / \mathrm{cm}^{3}$. Sintering clay materials leads to the reorganization of the matrix of the material during the appearance of the glassy phases at increasing kinetics with temperature [18]. The clay materials studied can then be favorable for the manufacture of ceramic products.

From Figure 9, it is noted that the values of compressive strengths decrease as the temperature increases. This implies that these materials melt at low temperatures and recrystallization occurs at temperatures above $1000^{\circ} \mathrm{C}$ [19].

Water absorption rates are shown in Figure 10.

Generally, the water absorption of ceramic products should decrease with the increase in firing temperature caused by the gradual disappearance of porosity during sintering [20]. The water absorption is closely related to the densification of the clay matrix, and gives an idea of the sintering rate. It can be seen that the rate of water absorption decreases as a function of temperature. For LO clay, for example, the absorption rate range from $16.35 \%$ at $1000^{\circ} \mathrm{C}$ to $14.26 \%$ at $1100^{\circ} \mathrm{C}$ and drops to $12 \%$ at $1200^{\circ} \mathrm{C}$. On the other hand, for NG clay, the water absorption 


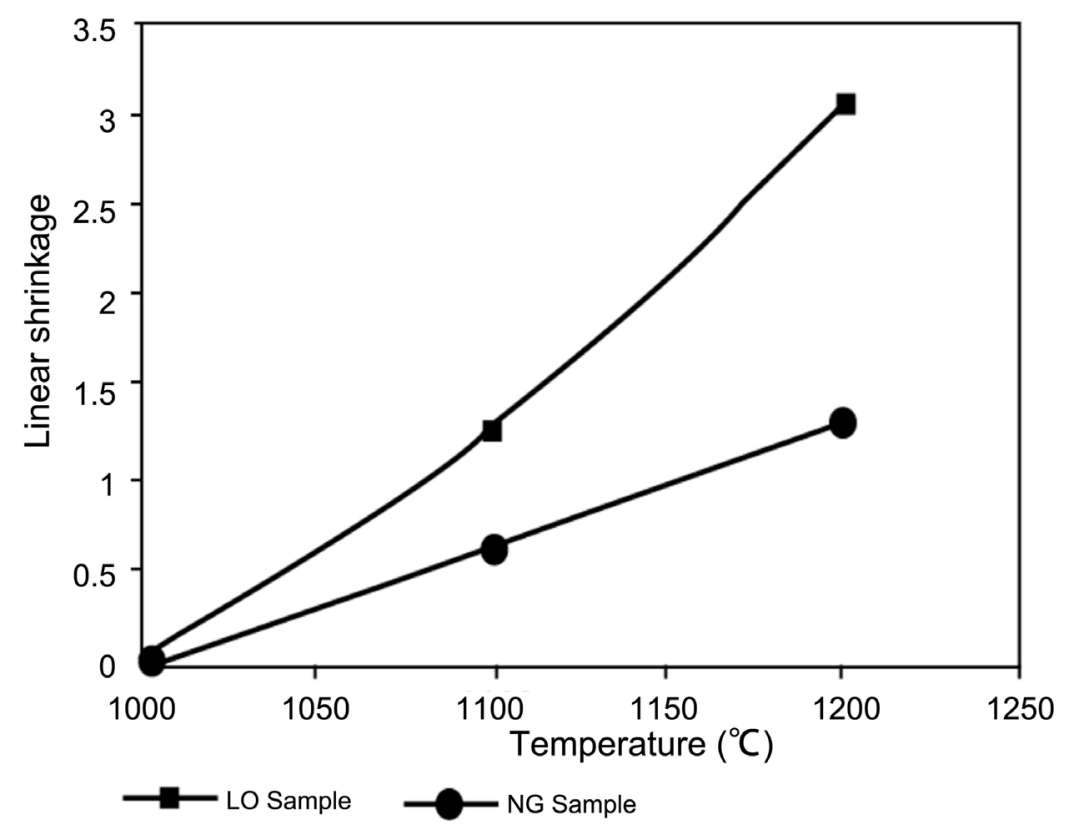

Figure 7. Variation of linear shrinkage as a function of temperature.

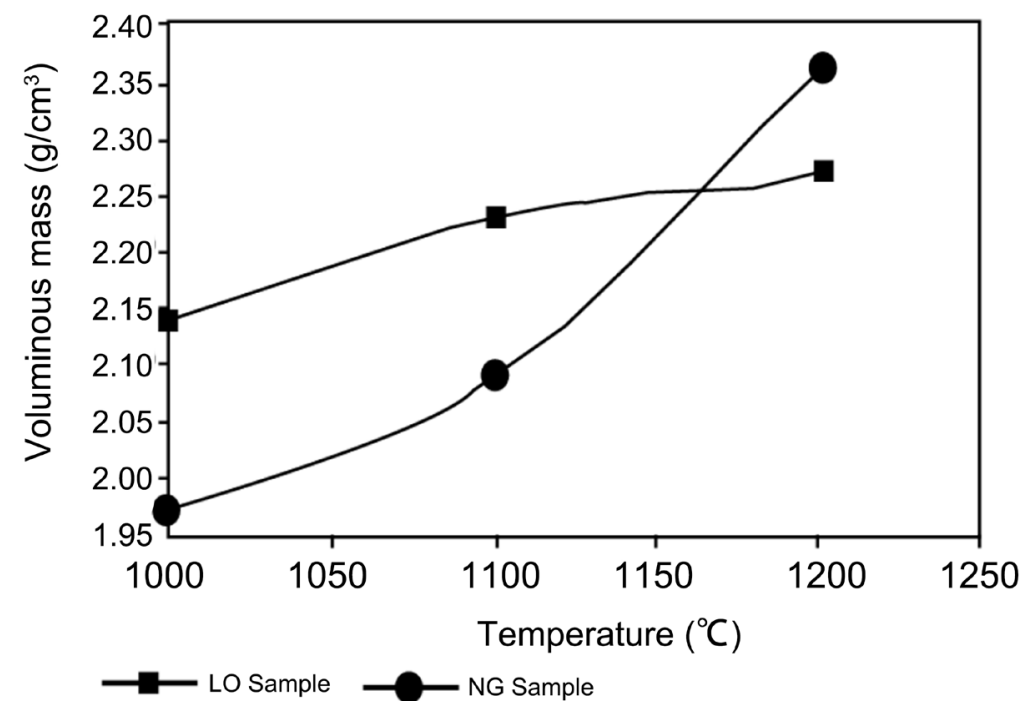

Figure 8. Variation of apparent density as a function of temperature.

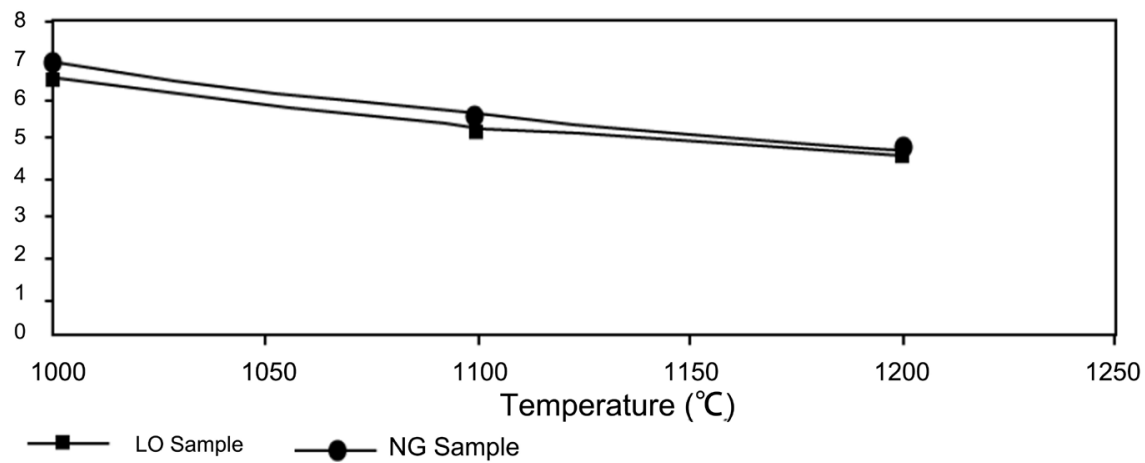

Figure 9. Resistance to compression as a function of temperature. 


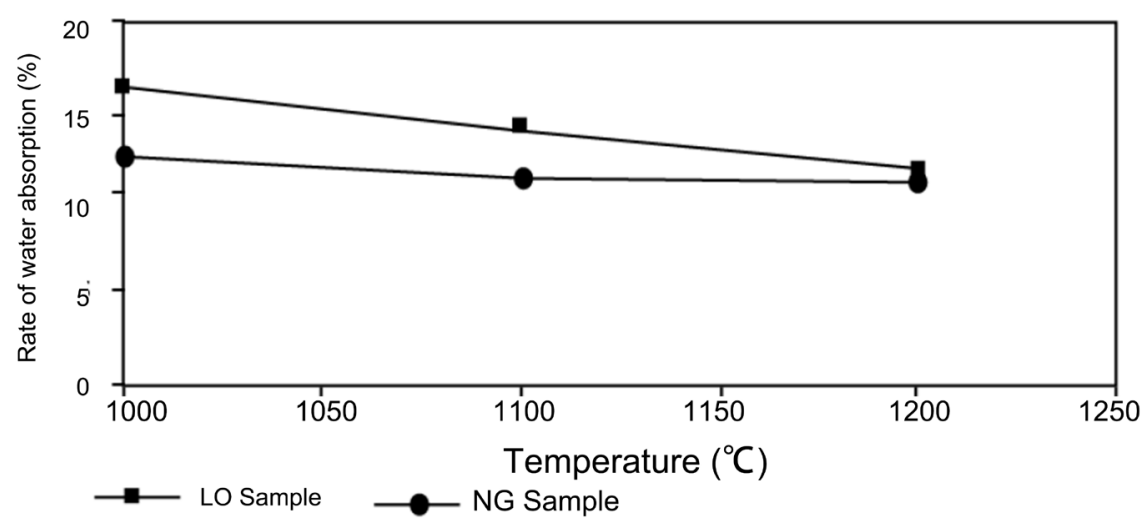

Figure 10. Change in water absorption rate as a function of temperature.

rate is $12.5 \%$ at $1000^{\circ} \mathrm{C}, 11.33 \%$ at $1100^{\circ} \mathrm{C}$ and $11.17 \%$ at $1200^{\circ} \mathrm{C}$. The NG sample absorbs less water than the LO sample.

\section{Conclusion}

LO and NG clay materials samples were subjected to various analyzes; particle size analysis reveals a continuous and spread granulometry. Atterberg limits of these clay materials reveal the low plasticity due to the high percentage of sand. Chemical analysis shows $\mathrm{SiO}_{2}: \mathrm{Al}_{2} \mathrm{O}_{3}$ ratio greater than 2 and other minerals such as quartz, illite, kaolinite, hematite and feldspars are also present. The thermal analysis shows characteristic mass losses of adsorbed water and kaolinite dehydroxylation to yield peak metakaolinite at $450^{\circ} \mathrm{C}-650^{\circ} \mathrm{C}$. The $\mathrm{pH}$ of these clay materials is weakly basic for LO sample while it is weakly acidic for NG sample. These clay materials have a low linear shrinkage due to their sandy nature, decreasing with temperature. The density and compressive strength increase with temperature while the rate of water absorption is low. These clay materials can then be used in the field of ceramic and the manufacture of bricks at a higher temperature $\left(1200^{\circ} \mathrm{C}\right)$

\section{Conflicts of Interest}

The authors declare no conflicts of interest regarding the publication of this paper.

\section{References}

[1] Nwoye, C.L. and Mbah, C.N. (2009) Effect of Porosity on the Shrinkage Behavior of Olokoro and Otamin Clays Sinters. Journal of Materials Engineering and Performance, 3, 359-368.

[2] Akudinobi, B.E.B. (2006) Aspect of Chemical and Mineralogical Assessment of Ukpor Clay, Nnewi South Local Government Area, Anambra State, Nigeria. Journal of Raw Materials Research, 3, 56-57.

[3] Nnuka, E.E. and Agbo, J.E. (2000) Evaluation of the Refractory Characteristics of Kwa Clay Deposit in Plateau State. Technical Transaction, 5, 32-59

[4] Guggenheim, S. and Martin, R.T. (1995) Definition of Clay and Clay Mineral: Joint 
Report of the Aipea Nomenclature and Cms Nomenclature Committees. Clays and Clay Minerals, 43, 255-256.

[5] Pialy, P. (2009) Etude de quelques matériaux argileux du site de Lembo (Cameroun): Minéralogie, comportement au frittage et analyse des propriétésd'élasticité. These de Doctorat/Ph.D., Universite de Limoges, Faculté des sciences ettechniques, Limoges.

[6] Osomba, W. (2012) Caractérisation et valorisation des matériaux argileux de laProvince de Kinshasa (RD Congo) These de Doctorat, Universite de Liège,

[7] El Yakoubi, N. (2006) Potentialité d'utilisation d'argiles marocaines de JbelKharron etde Benhmed dans l'industrie céramique. Comptes Rendus Géoscience, 338, 693-702.

[8] Harat, M. (2007) Contribution a l'amélioration du procédé de fabrication descéramiques. These de Magister, Génie des Procédés, Universite KasdiMerbahOuargla, Ouargla.

[9] Njopwouo, D. and Wandji, R. (1988) Minéralogie et comportement de quelquesargiles camerounaises au renforcement du caoutchouc naturel par voie humide. Annales de la Faculté des Sciences, Universite de Yaoundé I, Cameroon.

[10] Direction de la géologie et des mines (1979).

http://www.worldcat.org/title/carte-geologique-de-reconnaissance-du-cameroun-ga roua-ouest/oclc/81788746

[11] Lawou, K.S., Beyala K.K.V., Njopwouo, D. and Wouatong, A.S.L. (2012) Minéralogie et géochimie des matériaux d'altération du complexe de Bana (Ouest Cameroun): Genèse et evolution. Review CAMES-Série A, 13, 1-8.

[12] Tchouta, K.J.H., Wouatong, A.S.L., Ngapgue, F., Beyala, K.K.V. (2012) The Influence of Mineralogical and Geochemical Properties of Batié Sand and Conditions of Concrete Hardening on the Behavior of Structures. Electronic Journal of Geotechnical Engineering, 17, 1545-1557.

[13] Nnuka, E.E. and Apeh, M.O. (1991) Characterization of Ukpor Clay. The Nigerian Metallurgical Society Annual Conference Proceedings, 71-79.

[14] Nzeukou, N.A. (2014) Minéralogie, géochimie et propriétés céramiques des argiles alluviales de la Sanaga entre Nanga-Eboko et Ebebda (région du centre-Cameroun). Thèse de Doctorat Ph.D, Université de Yaoundé I, Cameroon, 18.

[15] Bomeni, Y. (2013) Caractérisation minéralogique et physico-chimique des matériaux argileux de Babouantou: Valorisation dans la céramique traditionnelle. Mémoire de magister, Université de Dschang, Dschang, 91.

[16] Koumtoudji, N. (2004) Transformations thermiques, organisation structurale et frittage des composés kaolinitique-muscovite. Université de Limoges, Limoges.

[17] Njoya, A., Nkoumbou, C., Grosbois, C., Njopwouo, D., Njoya, D., Courtin-Nomade, A.J. and Martin, F. (2006) Genesis of Mayouom Kaolin Deposit (Western Cameroon). Applied Clay Science, 32, 125-140. https://doi.org/10.1016/j.clay.2005.11.005

[18] Boch, P. (2001) Frittage et microstructure des céramiques et processus céramiques. Hermès Science Publication, Paris, 73-112.

[19] Kafra, T. (2003) Frittage à basse température d'une argile kaolinitique du Burkina Faso: transformation thermique et réorganisation structural. Thèse de Doctorat, Université de Limoges, Limoges.

[20] Njoya, A. (2007) Etude du gisement de kaolin de Mayouom (Foumban, Ouest Cameroun): Géologie, Minéralogie et Géochimie. Option géologie des matériaux, Université de Yaoundé I, Yaoundé, 142. 
[21] Elimbi, A., Njopwouo, D. and Wandji, R. (2001) Propriétés des produits de cuisson des argiles kaolinitique de Bomkoul (Cameroun) Acte 1ère Conf. Valorisation des matériaux argileux au Cameroun, Yaoundé, Cameroun, 91-100. 